https://doi.org/10.19195/0137-1150.173.37

Data przesłania artykułu: 22.09.2019

Data akceptacji artykułu: 28.12.2019

\author{
RADEK MALÝ \\ Uniwersytet Palackiego w Ołomuńcu, Czechy
}

\title{
Otisk válečné paměti v denících mladých Židů
}

Mezi literárními formami, které mají schopnost propůjčit slovo hrůzám války a holokaustu, zaujímají svou bezprostředností zvláštní místo deníky a memoáry. Deníky pak, s ohledem na to, že pamět', a ta literární zvláště, je velmi nespolehlivá, mohou v jistém smyslu sloužit jako jediný skutečně relevantní autentický literární dokument. Okolnosti a důvody vzniku deníku leží v oblasti mimoliterární, a tudíž literárním měřítkům nepodléhají. Deník málokdy vzniká jako záměrné literární dílo, a přece se jím po svém vydání stane. Známe však převážně jen ty deníky, které tuto hranici překročily, a právě tyto můžeme zkoumat a hodnotit. A není náhodou, že jedním z nejotřesnějších i nejproslulejších svědectví o holokaustu je světoznámý Deník Anny Frankové, který si mladá dívka ve svém amsterdamském úkrytu psala od třinácti do šestnácti let.

Deník Anne Frankové se stal do značné míry symbolem židovského utrpení za druhé světové války a dokonce se objevovaly pochyby o jeho pravosti - natolik plastickým literárním jazykem je psán a natolik daly nepříznivé okolnosti jeho pisatelce předčasně vyzrát, aby se v mladém věku dokázala vyslovit k závažným tématům způsobem, který nás dodnes fascinuje. Nejedná se však samozřejmě o jediné dílo tohoto typu. $Z$ evropských a do češtiny přeložených připomeňme např́ílad živým jazykem psané memoáry Naděje umírá posledni - očité svědectvi holokaustu polské Židovky Haliny Birenbaumové, která měla v okamžiku propuknutí druhé světové války deset let a prošla varšavským ghettem, úkryty i několika koncentračními tábory. Jinou v zahraničí úspěšnou knihou je Holocaust a válka očima dětí - utajené deniky, kniha, která vyšla v roce 1995 u př́ležitosti 50. výročí konce války v americkém nakladatelství Pocket Books. Jedná se o antologii dvaadvaceti deníků a zápisků, které si děti psaly v době druhé světové války po celé Evropě.

I v českém prostředí vzniklo hned několik silných deníkových záznamů mladých lidí z období druhé světové války. Tento příspěvek si nechce nárokovat úpl- 
nost jejich výčtu, všímá si však pozoruhodné vlny těchto textů v současné české literatuře: nebot' všechny vyšly knižně v rozmezí let 1997-2012. Jejich autory jsou muži i ženy, v rozmezí věku dvanácti až osmnácti let. Společnou mají snahu prostřednictvím deníkové sebereflexe popsat a pochopit svět kolem, svět, který se chová absurdně zle. Přitom se každý z těchto deníků stal literární událostí, byt' někdy mezinárodního, někdy lokálního významu. Otázkou, kterou si klademe, je, o čem tato intenzivní opožděná svědectví o holokaustu vypovídají.

Roku 2011 vyšel v nakladatelství Albatros Plus obsáhlý výbor z Deníků, které si v letech 1940-1946 vedla Hana Bořkovcová (rozená Knappová, 1927-2009), známá autorka především knih pro mládež. Její zápisky jsou unikátní časovým rozptylem - zaznamenávají události od doby začátku protižidovských opatření, přes tábory, osvobození až k návratu zpět do poválečného života. Více než rok prožila autorka v Terezíně, kde se věnovala péči o děti a také kulturnímu životu. V denících sledujeme jakoby mimoděk také postupné autorčino osobní zrání.

Je zarážející, že deníky Hany Bořkovcové vyšly až po její smrti. Stačí si však připomenout, jak komplikovaně se autorka dostávala k vlastnímu psaní a k tématu holokaustu. Její debut pro dospělé s názvem Světýlka vyšel až roku 1971, poté se autorka (také z důvodu nesouhlasu s komunistickým režimem) věnuje tvorbě pro mládež. Ovšem k tématu holokaustu se Bořkovcová vyslovuje až v devadesátých letech. Ohlas sklidila kniha nejprve kniha Zakázané holky (1995) o nerozlučném přátelství dvou dívek za protektorátu. A posledním autorčiným dílem vydaným za jejího života byl autobiograficky laděný román pro dospělé Soukromý rozhovor (2004). Deníky však nebyly podkladem pro tuto životopisnou knihu. Ty začal přepisovat až její manžel Aleš Bořkovec. Hana Bořkovcová však brzy nato umřela, aniž by konečnou verzi svých deníků viděla či se $\mathrm{k}$ ní mohla vyslovit. $\mathrm{V}$ ediční poznámce se tak dočteme, že záznamy byly v některých pasážích „cenzurovány“ rodinou — to jim však rozhodně neubírá na síle a naléhavosti.

Zatímco deníky Hany Bořkovcové se staly událostí v tuzemsku a byly oceněny Zlatou stuhou za nakladatelský počin, deník jiné dívky, Helgy Weissové, získal dokonce mezinárodní ohlas. Kniha s názvem Deník 1938-1945: Přiběh divvky, která přežila holocaust vyšla poprvé v nakladatelství Jota roku 2012, ale už vyšla v řadě evropských zemí, v USA a Izraeli. Předmluvu k této knize napsal Zdeněk Mahler a autorem doslovu je Ivan Klíma.

Deník pozdější akademické maliriřky Helgy Hoškové-Weissové (nar. 1929) je svědectvím dívky z pražské židovské rodiny. Helga svůj deník začala psát ve svých devíti letech, roku 1938, a jsme svědky tíživých ústrků, jimž se Židům v protektorátu dostávalo. Roku 1941 se Helga Weissová s rodinou dostala do Terezína, kde žila až do otcovy deportace do Osvětimi v roce 1944. Helga se svou matkou se rozhodly jej tam následovat, otec byl v Osvětimi zavražděn, ale Helga i její maminka přežily pobyt v Osvětimi i jiných táborech a vrátily se zpět do Prahy. Sešit, do kterého Helga své záznamy psala, její strýc zazdil v Terezíně a autorka mu mohla své další zážitky svěřit až ve svých patnácti letech. 
První české vydání je doprovázeno Helžinými dětskými ilustracemi i reprintem několika stránek z jejího deníku. Na tomto deníku je kromě jiného pozoruhodná autorčina ironie a místy i černý humor, s pomocí kterého se snad dařilo přežít nepochopitelná př́koří — to je aspekt, který najdeme i v jiných svědectvích, avšak nikde v takové míře.

Zvláštní osud měl deník Věry Kohnové(1929-1942), tehdy dvanáctileté židovské dívky z Plzně, která si jej psala od prázdnin 1941 do ledna 1942 — do odjezdu transportu plzeňských Židů do Terezína. Autorka sama byla z Terezína transportována do tábora v polském městě Izbica, z něhož se už nikdo z rodiny nevrátil. Svému deníku Věra Kohnová svěřovala zážitky ze zdánlivě obyčejného života v Plzni, bezelstným, jakoby bezstarostným tónem, který se však v lednu 1942 vytrácí.

Za války a po válce deníček uchovávala rodinná přítelkyně Marie Kalivodová. Ta jej později předala místnímu kazateli Jednoty bratrské Miroslavu Matoušovi a ten památníček odevzdal pražskému židovskému muzeu. Zásluhou Miroslava Matouše kniha vyšla v trojjazyčném vydání pod názvem Deník Věry Kohnové roku 2006 v nakladatelství Zdeňka Susy ve Středoklukách. Tento deník se svým pojetím asi nejvíce blíží deníkům Anny Frankové. Společná je jim věcnost popisu, ale zároveň cosi, co by se dalo nazvat „literárními ambicemi“. V dř́ívějším období, už na přelomu let trricátých a čtyřicátých, vznikaly zápisky Evy Rodenové (nar. 1924), které roku 2010 vydalo nakladatelství Prostor pod názvem Bylo mi patnáct: deník z let 1939-1940. Eva Rodenová svůj deník začala psát koncem listopadu 1939 a pokračovala s vynucenou odmlkou až do prosince roku 1944. Př́ed nástupem rodiny do transportu $\mathrm{v}$ roce 1942 se jí podařilo deník ukrýt u známých.

Po návratu domů v roce 1945 se $\mathrm{k}$ deníku ještě krátce vrátila. V záznamech dospívající dívky ještě zpočátku poznáváme iluzi společenského života, který se však odehrává výhradně uvnitř židovské komunity. Pisatelka dokonce zpočátku smí pokračovat ve studiu, byt' jen na soukromé škole. Zápisky Evy Rodenové citlivě a $\mathrm{z}$ dnešního pohledu až nemilosrdně odrážejí stísněnou atmosféru v protektorátu a vzrůstající útlak Židů — tím jsou její deníky v daném kontextu osobité a zasluhují naši pozornost.

Ze všech v tomto příspěvku zmíněných jmen je ve světě bezesporu nejznámějš́ jméno Petra Ginze (1928-1944), který zahynul jako šestnáctiletý v osvětimském táboře. Ve světě ho proslavila především kresba s názvem Měsiční krajina, kterou s sebou na oběžnou dráhu Země v raketoplánu Columbia roku 2003 jako memento holokaustu vynesl izraelský astronaut Ilan Ramon, jehož matka přežila Osvětim. Petr Ginz musel ve svých čtrnácti letech odejít do terezínského ghetta, kam následoval svou rodinu i přátele. Jeho zápisky z Prahy datující se od zář́ 1941 do února 1942, z období „ghetta beze zdí“, plasticky vykreslují život v prostoru přesně vymezeném nesčetnými zákazy. Nesoustřed’ují se na vnitřní pocity svého autora, ale spíše na věcný, avšak citlivý a empatický popis vnějších projevů útlaku. Nejsou zároveň prosty smyslu pro humor, jak dokládá tento záznam 
z 19. září 1941: „Počasí je mlhavé. Byl zaveden odznak pro Židy. Když jsem šel do školy, napočítal jsem 69 »šerifů «“1.

Tyto deníky zaznamenané ve dvou sešitech nalezené na půdě činžáku v Modřanech vešly ve známost až po tragédii raketoplánu roku 2003 a roku 2004 je v kompletní podobě vydala pod názvem Deník mého bratra Ginzova o dva roky mladší sestra Chava Pressburgerová. O inspirativnosti Petra Ginze a jeho tragického osudu svědčí i skutečnost, že na motivy deníků v USA roku 2012 vznikl dokumentární film s animovanými pasážemi Posledni let Petra Ginze a roku 2014 v České republice vyšla biografie s názvem Princ se žlutou hvězdou —život a podivuhodná putováni Petra Ginze, jejímž autorem je ředitel gymnázia Př́rodní škola František Tichý. I díky této knize se stal Petra Ginz jakousi celebritou, jejíž osud dojímá i inspiruje celou nastupující generaci mladých českých čtenářů.

Roku 2012 vyšla v nakladatelství Kvartus kniha s názvem Deník 1942-1945, jejímž autorem je Michal Kraus (1930), náchodský rodák a muž pozoruhodného osudu. V nacistických koncentračních táborech přišel o oba rodiče a strávil zde část svého dětství a jinošství. Přežil, díky souhře št’astných náhod a díky své pevné vůli, pobyt v Terezíně i Osvětimi, kde vykonával roli poslíčka, dva pochody smrti i skvrnitý tyfus, dočkal se osvobození koncentračního tábora Mauthausen a vrátil se do rodného města.

Deník si začal psát už $\mathrm{v}$ rodném Náchodě, pokračoval pak v terezínském ghettu, ale po př́jjezdu do Osvětimi musel všechno včetně deníku odevzdat. Znovu své vzpomínky sepsal jako patnáctiletý bezprostředně po osvobození a návratu domů. V červenci 1948 Michal Kraus emigroval do Kanady a originál deníku později věnoval Muzeu holokaustu ve Washingtonu a barevné kopie mají čtyři muzea v ČR a Izraeli. Autor nikdy neměl v úmyslu svůj deník zveřejnit, až ve svých 81 letech se rozhodl jej vydat, jak sám ř́ká, aby umožnil dnešní mladé generaci nahlédnout do stále ještě živé minulosti našeho kontinentu, na kterou by se nemělo zapomenout.

Všem dosud zmíněným deníkům se dostalo mediálně vděčného př́ízviska „česká verze Deniků Anne Frankové. Osud jejich pisatelů a obsah deníků se však liší - Anne Franková psala záznamy nikoli z koncentračních táborů, ale z doby svého skrývání se před nacisty. $V$ tomto ohledu je jejím deníkům nejpodobnější netypický osud posledního ze zde jmenovaných, mladého moravského Žida Otty Wolfa (1927-1945). Ačkoli se narodil v Mohelnici, žil se svou rodinou v Tršicích na Olomoucku. Od roku 1942, kdy mu bylo patnáct let, zaznamenával osudy své rodiny do deníku, který knižně vyšel roku 1997 pod názvem Deník Otty Wolfa 1942-1945 v nakladatelství Sefer s doslovem a úpravami Ivana Klímy a v péči a s předmluvou olomouckého germanisty Ludvíka Václavka.

Wolfova rodina se roku 1942 před deportací zachránila v úkrytu v lese nedaleko Tršic a v různých skrýších část rodiny za pomoci českých vesničanů přežila zbytek války až do osvobození. Pisatele deníků Otto Wolfa, který se přidal k partyzánům,

${ }^{1}$ C. Pressburger, P. Ginz, Deník mého bratra, Praha 2004, s. 32. 
v dubnu 1945 zajali a umučili ruští vojáci ve službách fašistů. Chlapec úkryt své rodiny neprozradil a o jeho smrti se jeho blízcí dozvěděli až několik dnů po osvobození. V psaní rodinné kroniky ještě nějaký čas pokračovala jeho starší sestra. Místo úkrytu rodiny se i díky mezinárodnímu ohlasu deníků stalo poutním místem a jejich detailní dokumentárnost je fascinující především v tom, jakým způsobem jsou zde vylíčeny různé př́ístupy nežidovských obyvatel Tršic k ukrývané rodině.

Setkáme se i s př́ípady, že autoři (častěji autorky) své deníky doplňují o vlastní pozdější vyprávění (to dokonce v mnoha případech převáží), a vzniká tak přechodný útvar na pomezí dvou forem — deníků a memoárů. Není divu — zápisy zapsané z pozice dítěte prrímo volají po interpretaci dospělým pohledem. Je to i př́ípad Kateřiny Pošové (1930-2008) a její knihy Jsem, protože musím... napsala jsem si ve čtrnácti do lágrového deníku (2003).

Kateřina Pošová (rozená Bárkány) se narodila v Kežmaroku v židovské rodině architekta a stavitele. Dětství prožila v tehdy mad’arských Košicích a jako čtrnáctiletá byla v červnu 1944 s rodiči deportována do Osvětimi a následně i do dalších koncentračních táborů. Z její rodiny nikdo jiný holokaust nepřežil. Kateřina Pošová pracovala jako tlumočnice a překladatelka v Mad’arském kulturním institutu v Praze (přeložila např́klad román Imre Kertésze Člověk bez osudu).

Deník si mladá Kateřina Pošová psala od prosince 1944 mezi svými čtrnácti a patnácti lety a dala mu podobu dopisů otci. Toho viděla naposledy na rampě nádraží v Osvětimi a doufala, že se s ním po válce shledá. Samotná kniha Jsem, protože musím ... napsala jsem si ve čtrnácti do lágrového deníku vznikala několik let na základě rozhovoru publicistky Pavly Frýdlové s autorkou deníku po více než padesáti letech od jeho napsání. Autentický deník je vřazen doprostřed knihy na jeho místo, kam podle chronologie patří. Původně se jednalo o oranžový sešit, který mladá dívka v táboře vyměnila za porci chleba a polévky. Politováníhodné je, že když tento text autorka roku 1960 zaslala do literární soutěže k 15. výročí osvobození Československa, byl opomenut, a tak na své vydání čekal dalších více než čtyřicet let. Knižně vyšel až roku 2003 v nakladatelství Prostor. V ukázce z deníku Kateřiny Pošové ze dne 12. dubna 1945 je zřejmé, jak sugestivní je zvolená forma dopisů tehdy už mrtvému otci:

Na tyhle své patnácté narozeniny, i kdybych žila sto dvacet let, určitě nikdy nezapomenu. Ani nevím, tatínku, kde mám začít $\mathrm{s}$ vyprávěním. Ráno jsme už byly v práci a právě když jsme snídaly, přišla aufseherka, že dostali telefonickou zprávu, abychom se okamžitě ze všech komand vrátily do lágru. Přesně tak to probíhalo i u mužůu, když je potom hned odvezli. Nikdo nevěděl, co to znamená, mistr byl strašně dojatý, skoro plakal a všem nám podal tu svou jednu ruku. Honem honem jsme se vrátily do lágru, netušily jsme, jestli pojedeme nebo ne, pak byl apel a nás všech pět set žen vypochodovalo strašně daleko, asi na 2-3 hodiny cesty, kopat zákopy. Celý den jsme pak slyšely vzdálené dunění, přicházelo to stále blíž a blíž a pak jsme najednou uviděly docela blízko veliký požár, plápolalo to a kouřilo, granáty svištěly a my jsme se vydaly na zpáteční cestu do lágru a po silnici proti nám stále jen přicházeli a utíkali vojáci, civilové, pěšky, na kolech, v autech, kdo co měl. [...] Tak takové to byly narozeniny, tatínku. Jestli to všechno nějak dobře dopadne, pak jsem vlastně právě já dostala ten nejkrásnější dárek k patnáctým narozeninám! Ale tolik jsem na Tebe včera myslela a myslím pořád, tatínku! Jak 
by se ta celá situace líbila Tobě! A je vlastně pravděpodobné, že už jsi prožil nebo brzy prožiješ i Ty něco podobného².

V podobném duchu, byt' možná ne tak sugestivním stylem, jsou psány i další memoáry, v nichž jsou zakomponované dětské deníky. Jde např́klad o knihu Renaty Laxové (rozené Polgarové, nar. 1931) Dopis Alexandrovi (2010) a o knížku Věry Gissingové (rozené Diamantové, nar. 1929) s názvem Perličky dětství (1988, v českém překladu 1992). Obě autorky patří k Wintonovým dětem zachráněným z Československa v transportech Nicholase Wintona ve Velké Británii a jejich vzpomínkové knihy se zčásti opírají o zápisky, které si jako děti pořídily v adoptivních rodinách.

Každý ze jmenovaných deníků za sebou skrývá silné př́běhy, které by si zasloužily podrobnější komentář. Smyslem tohoto příspěvku však je především poukázat na množství a různorodost deníkové tvorby Čechů židovského původu, kteří byli nuceni vyrovnávat se $\mathrm{s}$ holokaustem v době svého mládí. Skutečnost, že všechny tyto deníky se značnými ohlasy vyšly až v současnosti, svědčí o aktuálnosti problematiky i o živosti a literární úrovni záznamů. Nejcennější je na nich dodnes jejich autentičnost, o níž např́ílad svědčí přeskoky mezi věcmi nepodstatnými k hrozivým a přesným záznamům bezútěšné reality.

Na závěr připojme jedou drobnou relevantní ukázku, zápis Hany Bořkovcové z 24. ledna 1942: „Jiřina ř́ká, že je dobře psát si deník a pozorovat se. Budu to tedy dělat, také proto, že občas ráda píši, ačkoli mi není jasné, proč bych stála za velké pozorování‘ ${ }^{\prime 3}$. Ano, je dobře psát si deník a pozorovat se, a s odstupem času je také naprosto jasné, proč zmínění autoři deníků z doby holokaustu skutečně stojí za velké pozorování: pro nesmlouvaný, žalující, ale zároveň bezelstný pohled mladého člověka, kterému do života vstoupila válka. Jsou to dnes pro svou autenticitu cenné dokumenty, které vypovídají o nezlomnosti lidského ducha na jeho touze po svobodě a lásce za těch nejnepř́větivějších okolností.

\section{Bibliografie}

Birenbaumová H., Naděje umirá posledni - očité svědectvi holokaustu, Jota, Praha 2010.

Blažíček P., Deník jako literární útvar, „Prostor“ 1993, č. 24.

Boerner P., Tagebuch, J.B.Metzlersche Verlagsbuchhandlung, Stuttgart 1969.

Bořkovcová H., Píšu a sešit mi leži na kolenou, Nakl. Plus, Praha 2011.

Franková A., Denik, Triáda, Praha 2006.

Gissingová V., Perličky dětství, Odeon, Praha 2009.

Hoffmannová J., Paradoxy deníkové a memoárové literatury, „Tvar“ 1995, č. 20.

Hollidayová L., Holocaust a válka očima dětí - utajené deníky, Prostor, Praha 1997.

Hybler M., Pamět paměti, „Kritická příloha. Revolver Revue“ 2001, č. 20.

Kohnová V., Deník, Zdeněk Susa, Středokluky 2006.

Kraus M., Deník 1942-1945, Kvartus, Náchod 2012.

${ }^{2}$ K. Pošová, Jsem, protože musím... napsala jsem si ve čtrnácti do lágrového deníku, Praha 2003, s. 129.

${ }^{3}$ H. Bořkovcová, Píšu a sešit mi leži na kolenou, Praha 2011, s. 19.

Slavica Wratislaviensia 173, 2020

(C) for this edition by CNS 
Laxová R., Dopis Alexandrovi, Barrister \& Principal, Brno 2010.

Pošová K., Jsem, protože musím... napsala jsem si ve čtrnácti do lágrového deníku, Prostor, Praha 2003.

Pressburger Ch., Ginz P., Deník mého bratra, Trigon, Praha 2004.

Rodenová E., Bylo mi patnáct: deník z let 1939-1940, Prostor, Praha 2010.

Rodenová E., Roden R., Životy ve vypůjčeném čase, Academia, Praha 2007.

Tichý F., Princ se žlutou hvězdou —život a podivuhodná putování Petra Ginze, Geum, Semily 2014.

Weissová H., Deník 1938-1945: přiběh divky, která přežila holocaust, Jota, Brno 2012.

Wolf O., Deník Otty Wolfa 1942-1945, Sefer, Praha 2011.

\section{Diaries of Young Jews in the Time of the Holocaust}

\section{Summary}

This paper focuses on the diaries of young Jewish people during World War II. Specifically it denotes the texts of Hany Bořkovcová, Otto Wolf, Helga Weiss-Hošková, Věra Kohnová, Eva Rodenová, Petr Ginz, Michal Kraus and Kateřina Pošová - to name only a few. Every one of them was given the nickname "The Czech Anne Frank." What is surprising is the sheer number of these diaries, but also the fact that all came to public attention recently. They imply the topicality of the issue as well as the vibrancy and literary level records. The most valuable thing to this day is not their literary quality, but their simple authenticity. It points out that even in a gloomy reality it was possible to see hope and humanity.

Keywords: diary, Holocaust, Jew, Czech Literature, World War II

\section{Dzienniki młodych Żydów w epoce Holokaustu}

\section{Streszczenie}

W artykule autor koncentruje uwagę na pamiętnikach młodych Żydów z czasów II wojny światowej. Analizuje teksty Hany Bořkovcovej, Otto Wolfa, Helgi Weiss-Hoškovej, Věry Kohnovej, Evy Rodenovej, Petra Ginza, Michala Krausa i Kateřiny Pošovej. Każdy z nich otrzymał przydomek „,zeska Anne Frank”. Zaskakująca jest już sama liczba tych pamiętników, ale także fakt, że wszystkie ujrzały światło dzienne dopiero niedawno. Poruszana w nich problematyka jest aktualna, a treści i wartość literacka tych tekstów nadal znajdują oddźwięk. Dziś najcenniejsza jest w nich autentyczność, którą widać na przykład w nagłych przeskokach między opisami codziennych drobiazgów a szczegółową dokumentacją wyjątkowej i brutalnej rzeczywistości wojennej.

Stowa kluczowe: dziennik, Holokaust, Żyd, literatura czeska, II wojna światowa 